\title{
'HoneySweet' (C5), the First Genetically Engineered Plum pox virus-resistant Plum (Prunus domestica L.) Cultivar
}

\section{Ralph Scorza ${ }^{1}$}

U.S. Department of Agriculture, Agricultural Research Service, Appalachian Fruit Research Station, 2217 Wiltshire Road, Kearneysville, WV 25430

\section{Michel Ravelonandro}

Unite Mixte de Recherche Biologie du Fruit et Pathologie, UMR-BFP-1332, INRA-Bordeaux, 71 avenue Bourlaux, 33882 Villenave d'Ornon, France

\section{Ann Callahan}

U.S. Department of Agriculture, Agricultural Research Service, Appalachian Fruit Research Station, 2217 Wiltshire Road, Kearneysville, WV 25430

\section{Ioan Zagrai}

Statiunea de Cercetare-Dezvoltare pentru Pomicultura, Bistrita, Drumul Dumitrei Nou, nr. 3, Cod 420127 Judetul Bistrita-Năsăud Bistrita, Romania

\section{Jaroslav Polak}

Department of Virology and Phytoplasmatology, Crop Research Institute, Drnovska 507, 16105 Prague, Czech Republic

\section{Tadeuz Malinowski}

Research Institute of Horticulture, Pomologiczna 18, PL 96-100 Skierniewice, Poland

\section{Mariano Cambra}

IVIA, Plant Protection and Biotechnology Centre, Carretera Moncada-Náquera km 5, 46113 Moncada-Valencia, Spain

\section{Laurene Levy}

U.S. Department of Agriculture, Animal and Plant Health Inspection Service, Plant Protection and Quarantine, 4700 River Road, Unit 152, 5C-03.50, Riverdale, MD 20737-1232

\section{Vern Damsteegt}

U.S. Department of Agriculture, Agricultural Research Service, Foreign Disease-Weed Science Research, Fort Detrick, MD

Boris Krška

Department of Fruit Growing, DFG FH, Mendel University, Valtická 337, 69144 Lednice, Czech Republic

\section{John Cordts \\ Cordts Consulting LLC, Newark, DE}

\section{Dennis Gonsalves}

U.S. Department of Agriculture, Agricultural Research Service, Daniel K. Inouye U.S. Pacific Basin Agricultural Research Center, Hilo, HI 96720

\section{Chris Dardick}

U.S. Department of Agriculture, Agricultural Research Service, Appalachian Fruit Research Station, 2217 Wiltshire Road, Kearneysville, WV 25430

Additional index words. plum, genetic engineering, Plum pox virus, sharka, black knot, Rosaceae

\section{Origin}

'HoneySweet' originated as a seedling from the open pollination of 'Bluebyrd' plum (Scorza and Fogle, 1999). The pollen parent of 'HoneySweet' is unknown. 'HoneySweet' was originally selected in vitro as a regenerated shoot from a hypocotyl slice that had been transfected with Agrobacterium tumefaciens EHA 101 carrying the plasmid
pGA482GG/PPV-CP-33 (Scorza et al., 1994). The regenerated, transgenic shoot, coded as $\mathrm{C} 5$, along with other transgenic shoots, was rooted in vitro and transferred to a greenhouse. Following greenhouse testing using graft and aphid inoculations with the $\mathrm{M}$ and $\mathrm{D}$ strains of Plum pox virus (PPV), C5 (later patented as 'HoneySweet'), was asexually propagated by bud grafting on to standard rootstocks, including Prunus persica (GF305 peach seedlings), Prunus domestica (European plum seedlings), Prunus myrobalan, and GF 8-1 (Prunus cerasifera $\times P$. munsoniana). An overview of the development of 'HoneySweet' plum and molecular characterization can be found in Scorza et al. (2013a).

\section{Description}

'HoneySweet' has been evaluated in Skierniewice, Poland, Llíria-Valencia, Spain, Bistrita, Romania (Fig. 1), Prague, Czech Republic (Table 1), and Kearneysville, WV. 'HoneySweet' trees have an upright growth habit and moderate level of fruiting-spur development. Flowering in Kearneysville, $\mathrm{WV}$, occurs in late March to mid-April or $\approx 5-10 \mathrm{~d}$ before 'Stanley' depending on environmental conditions. In Kearneysville, $\mathrm{WV}$, and in the European test plots, depending on environmental conditions, 'HoneySweet' fruit ripen in early- to mid-August or $\approx 10$ $20 \mathrm{~d}$ before the ripening of 'Stanley' plum. 'HoneySweet' fruit evaluated in Kearneysville, $\mathrm{WV}$, are medium to large in size with an average weight of $60 \mathrm{~g}(\approx 2 \mathrm{oz})$ and average dimensions of $43-45 \mathrm{~mm}\left(\approx 1.75^{\prime \prime}\right)$ in diameter and $52 \mathrm{~mm}\left(\approx 2^{\prime \prime}\right)$ in length. Flesh is yellow, firm, juicy, and sweet $\left(20-22{ }^{\circ}\right.$ Brix in U.S. and Spain tests) with a pleasing flavor balance. The skin is a deep purple with a waxy overcoat. The stone is mostly free with only a small area of adhesion to the flesh. Additional analyses of 'HoneySweet' fruit composition can be found in Ravelonandro et al. (2013) and Sochor et al. (2015).

Myrobalan (P. cerasifera) rootstocks are not recommended for 'HoneySweet' due to overgrowth of the 'HoneySweet' scion at the graft union. 'HoneySweet' trees grafted on to GF 8-1 rootstocks observed for over a decade of field testing have performed well and without signs of overgrowth. Limited observations suggest that peach $(P$. persica) is also a suitable rootstock for 'HoneySweet'.

A detailed description of 'HoneySweet' may be found in the 'HoneySweet' plant patent (US PP15154 P2).

'HoneySweet' is self-incompatible. It has fruited consistently and abundantly in mixed plantings of $P$. domestica plum varieties. When 'HoneySweet' was used as a female parent in limited controlled crosses, it was shown to be compatible with $P$. domestica plums 'Castelton', 'Jojo', 'LongJohn', 'Victory', 'Vision', and 'C11' [U.S. National Plant Germplasm System (NPGS), Davis, CA, accession DPRU 2266] 'Anna Spath', 'Cacanska Lepotica', 'Cacanska Rana', and 'Reine Claude de Bavay'. Fruit were not produced from limited controlled crosses 


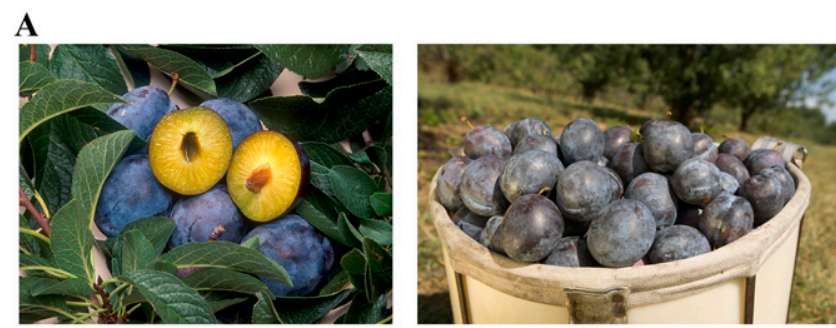

B

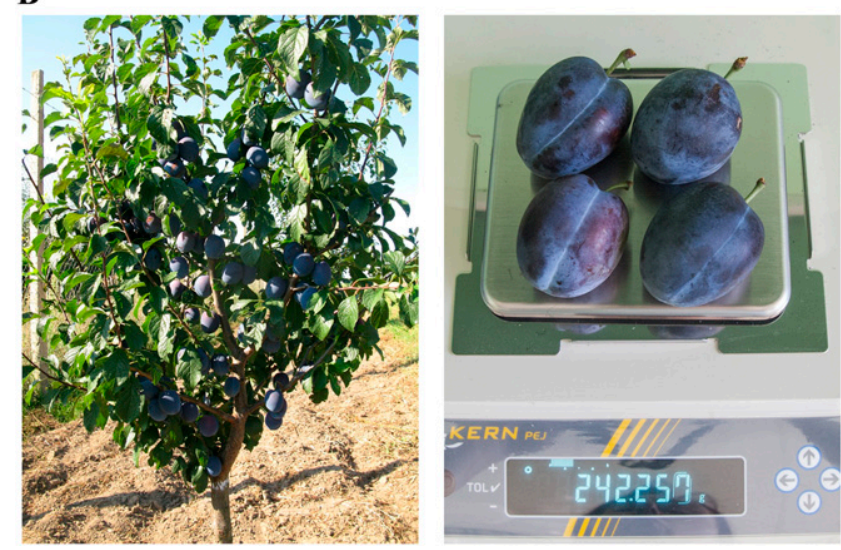

Fig. 1. (A) 'HoneySweet' plum (left); 'HoneySweet' plum harvest at the U.S. Department of AgricultureAgricultural Research Service, Kearneysville, WV (right). (B) Three-year old 'HoneySweet' tree in Bistrita, Romania (left), with a weighed sample of 'HoneySweet' fruit (right). Photo credits: Scott Bauer, Peggy Greb, and Ioan Zagrai.

with pollen of 'President', 'Stanley', 'Improved French', and 'Sutter'. Since, as a $P$. domestica species, 'HoneySweet' is a hexaploid, it is sexually incompatible with most other Prunus species including peach and nectarine, 'Japanese' plum (Prunus salicina), apricot (Prunus armeniaca), sweet (Prunus avium) and sour (Prunus cerasus) cherry, and almond (Prunus dulcis).

'HoneySweet' is heterozygous for the PPV-CP insert; therefore $\approx 50 \%$ of the male and female gametes leading to pollen and egg development will contain the PPV-resistance transgene. When used as a parent in conventional hybridization, 'HoneySweet' transfers the PPV-CP transgene insert to progeny as a single dominant locus and, as predicted by Mendelian genetics, $\approx 50 \%$ of the progeny carry the transgene insert. These are resistant to PPV (Ravelonandro et al., 2002; Scorza et al., 1998), making 'HoneySweet' a useful source of resistance for developing additional PPV-resistant cultivars. 'HoneySweet' is also

Received for publication 20 Aug. 2015. Accepted for publication $18 \mathrm{Feb} .2016$.

We extend our appreciation to the following for their contributions to the over 20-year process of research, development, and evaluation of 'HoneySweet' plum: Pascal Briard, Nieves Capote, Mark Demuth, Marc Fuchs, Laura Georgi, Jean-Michel Hily, Ivanka Kamenova, Jiban Kumar, Nicolae Minoiu, Andrew Stone, Kevin Webb, Luminata Zagrai, and Barbara Zawadzka. We gratefully acknowledge Cheryl Vann for statistical analyses of fruit quality data.

${ }^{1}$ Corresponding author. E-mail: ralph.scorza@ ars.usda.gov. highly resistant to black knot disease caused by the fungus Apiosporina morbosa. It appears to have inherited this resistance from 'Bluebyrd', its seed parent, which is also highly resistant to black knot (Scorza and Demuth, 2015).

The expression of the uidA (GUS) gene in the PPV-CP cassette allows for the rapid identification of seedlings carrying the PPV-CP insert through a simple and rapid histochemical assay (Jefferson, 1987). Polymerase chain reaction (PCR) can be used to confirm the presence of the hairpin-PPV-CP insert using specific primers for the hairpin insert [C5 ForwardGTGCATTGCAGAAGCAAC and 35S Reverse-CGCAATGATGGCATTTGTAGG resulting in a 675-base amplicon using Go TAQ polymerase (Promega, Madison, WI) and an amplification program consisting of 2 min at $95.0{ }^{\circ} \mathrm{C}, 30$ cycles of $1 \mathrm{~min}$ each at $95.0^{\circ}, 59.0^{\circ}$, and $72.0^{\circ}$, followed by a $10-\mathrm{min}$ extension at $72.0{ }^{\circ} \mathrm{C}$, or for real-time PCR: primer 1-GGTAGTTCCCACTGAATC AAAGGC, primer 2-TTATTTCAACGCCA GTCCTGTCCC, and probe-56-FAM/ TGGCAAGGA/ZEN/AATGTGCGAGTTC TGT/31ABkFQ (IDT, Coralville, IA) following the protocol in Scorza et al. (2013b).

\section{PPV Resistance}

Sharka disease caused by PPV affects most stone fruit species, cultivated and wild (Damsteegt et al., 2007). Symptoms of Sharka disease are described in Levy et al. (2000). Although resistance to PPV has been pursued ever since the disease was first identified, there are few reports of high-level resistance in commercial Prunus species and new sources of high-level resistance to PPV are needed.

Initial 'HoneySweet' PPV-resistance tests were greenhouse-based (Ravelonandro et al., 1997). Although no PPV field inoculations were performed in the United States due to the quarantine status of PPV, through nearly 20 years of field testing in Europe, under heavy natural aphid-vectored infection pressure, of the 99 trees of 'HoneySweet' that have been evaluated, none have become infected with PPV through natural aphid transmission, whereas control trees have become rapidly and severely infected.

When graft inoculated with PPV-infected budwood or when vegetative "root suckers" from susceptible rootstocks have become infected, 'HoneySweet' trees have shown scarce and mild symptoms in the basal leaves near the source of infection. Systemic infection has generally not been detected, but when detected, it has been limited with mild symptoms that have diminished over multiple growing seasons (Polak et al., 2012). 'HoneySweet' trees have been shown to be resistant to all major strains of PPV (Ravelonandro et al., 2014). When grafts were inoculated with PPV in combination with Prunus necrotic ringspot virus, Apple chlorotic ringspot virus, and Prune dwarf virus, 'HoneySweet' has remained resistant to PPV (Polak et al., 2013; Ravelonandro et al., 2013; Zagrai et al., 2008). Details of PPV resistance in field trials of 'HoneySweet' can be found in Hily et al. (2004), Malinowski et al. (2006), Polak et al. (2008), Zagrai et al. (2011), and Capote et al. (2008).

PPV is not currently affecting the U.S. plum production; however, this virus remains as a significant threat. The U.S. Department of Agriculture-Agricultural Research Service (USDA-ARS) release of 'HoneySweet' makes this cultivar available for cultivation in the United States and provides a genetic resource for breeding additional PPV-resistant varieties.

\section{Coexistence}

Considering coexistence of 'HoneySweet' with conventional or organic plum production, pollen-mediated gene flow in $P$. domestica has been found to be very low. Furthermore, unlike crops where gene flow manifests in seeds which are the products of commerce such as soybean and maize, plum seeds are not consumed and are rarely used for planting purposes. Pollen-mediated gene flow from a plot of genetically engineered (GE) $P$. domestica plums, including 'HoneySweet', was evaluated for 11 years (Scorza et al., 2013b). Under the study conditions, gene flow measured as the number of GUS-positive seeds detected in conventional plum fruits occurred in only 4 of 11 years and then in only $0.31 \%$ of the 12,116 seeds analyzed. Spatial modeling indicated that the low levels of gene flow decreased dramatically to zero or near zero at distances over $400 \mathrm{~m}$ from the GE plot. In this same study, no GE plum trees were found in fields or forested areas adjacent to the GE plum plot, 
Table 1. Comparisons of 'HoneySweet' fruit characteristics in 2011, 2012, and 2014, Prague, Czech Republic.

\begin{tabular}{|c|c|c|c|c|c|c|c|}
\hline \multirow[b]{2}{*}{ Cultivar } & \multicolumn{7}{|c|}{ Characteristics } \\
\hline & Fruit wt $(\mathrm{g})$ & Fruit length (mm) & Fruit width $(\mathrm{mm})$ & Fruit thickness (mm) & Flesh thickness (mm) & \% Soluble solids & $\%$ Fruit wt in stone \\
\hline HoneySweet & $56.2 \pm 1.98$ & $46.6 \pm 0.64$ & $39.7 \pm 0.65$ & $37.6 \pm 0.66$ & $11.5 \pm 0.31$ & $16.9 \pm 0.27$ & No data \\
\hline JoJo & $23.9 \pm 0.33$ & $39.6 \pm 0.25$ & $29.2 \pm 0.18$ & $29.7 \pm 0.18$ & $6.4 \pm 0.21$ & $12.1 \pm 0.36$ & No data \\
\hline$P$ value & $<0.0001$ & $<0.0001$ & $<0.0001$ & $<0.0001$ & $<0.0001$ & $<0.0001$ & - \\
\hline \multicolumn{8}{|l|}{2012} \\
\hline HoneySweet & $48.0 \pm 2.61$ & $50.3 \pm 1.02$ & $40.7 \pm 0.89$ & $39.9 \pm 1.50$ & $14.4 \pm 0.57$ & $14.2 \pm 0.73$ & $4.9 \pm 0.34$ \\
\hline$P$ value & $<0.0001$ & 0.0430 & $<0.0001$ & $<0.0001$ & $<0.0001$ & $<0.0001$ & 0.0032 \\
\hline \multicolumn{8}{|l|}{2014} \\
\hline HoneySweet & $60.7 \pm 3.04$ & $46.2 \pm 0.90$ & $43.6 \pm 0.74$ & $41.5 \pm 0.97$ & $11.2 \pm 0.33$ & $16.1 \pm 0.51$ & $3.5 \pm 0.12$ \\
\hline JoJo & $46.4 \pm 1.39$ & $50.5 \pm 0.71$ & $38.1 \pm 0.74$ & $35.7 \pm 0.35$ & $7.6 \pm 0.20$ & $18.9 \pm 0.54$ & $4.3 \pm 0.11$ \\
\hline Stanley & $36.0 \pm 2.11$ & $50.1 \pm 0.61$ & $36.0 \pm 0.47$ & $30.1 \pm 0.48$ & $6.3 \pm 0.19$ & $19.2 \pm 0.47$ & $5.1 \pm 0.09$ \\
\hline$P$ value & $<0.0001$ & 0.0003 & $<0.0001$ & $<0.0001$ & $<0.0001$ & 0.0002 & $<0.0001$ \\
\hline
\end{tabular}

Multivariate analysis of variance for cultivar differences/year: 2011 Wilk's lambda $=0.01633, \mathrm{~F}=39.58 ; 2012 \mathrm{Wilk}$ 's lambda $=0.06316, \mathrm{~F}=13.81 ; 2014 \mathrm{Wilk}$ 's lambda $=0.02529, \mathrm{~F}=20.19$. Values are means $\pm \mathrm{SE}$.

indicating that over the 11 years of the study, there was no seed-based gene flow from GE plum trees. These results support the feasibility of coexistence of GE and non-GE plum orchards.

\section{Availability}

'HoneySweet' was deregulated by the U.S. Animal and Plant Health Inspection Service in 2007, was reviewed by the U.S. Food and Drug Administration in 2009, and was registered by the Environmental Protection Agency in 2011 (Scorza et al., 2013a). 'HoneySweet' was awarded a U.S. plant patent in 2004, but is being made freely available for fruit production and for use as a source of PPV resistance for developing new PPV-resistant $P$. domestica plum varieties in the United States. Currently, 'HoneySweet' plum has not received approval for cultivation in the EU or other locations outside of the United States. 'HoneySweet' is being made freely available to requestors outside of the United States contingent upon the certification that appropriate foreign regulatory approvals have been obtained by the requestor.

The Agricultural Research Service has no trees of 'HoneySweet' for distribution. A limited amount of heat-treated budwood of 'HoneySweet' is available from Clean Plant Center Northwest-Fruit Trees (CPCNW-FT) (http://cpcnw.wsu.edu/ fruit-trees/bud-buying). Genetic material of this release will be deposited in the NPGS where it will be available for research purposes, including development and commercialization of new cultivars.

The recipient of genetic material from CPCNW-FT or NPGS of 'HoneySweet', including but not limited to, buds, pollen, and seeds is subject to the conditions stated in the USDA-ARS 'HoneySweet' Cultivar Release Notice. The 'HoneySweet' release notice and additional information on 'HoneySweet' and PPV can be found at http://www.ars.usda.gov/ is/br/plumpox/.

\section{Literature Cited}

Capote, N., J. Perez-Panades, C. Monzo, E. Carbonell, A. Urbaneja, R. Scorza, M. Ravelonandro, and M. Cambra. 2008. Assessment of the diversity and dynamics of Plum pox virus and aphid populations in transgenic European plums under Mediterranean conditions. Transgenic Res. 17:367-377.

Damsteegt, V.D., R. Scorza, A.L. Stone, W.L. Schneider, K. Webb, M. Demuth, and F.E. Gildow. 2007. Prunus host range of Plum pox virus (PPV) in the United States by aphid and graft inoculation. Plant Dis. 91:18-23.

Hily, J.M., R. Scorza, T. Malinowski, B. Zawadzka, and M. Ravelonandro. 2004. Stability of gene silencing-based resistance to Plum pox virus in transgenic plum (Prunus domestica L.) under field conditions. Transgenic Res. 13:427-436.

Jefferson, R.A. 1987. Assaying chimeric genes in plants: The GUS gene fusion system. Plant Mol. Biol. Rpt. 5:387-405.

Levy, L., V. Damsteegt, R. Scorza, and M. Kolber. 2000. Plum pox potyvirus disease of stone fruits. APSnet Features. Online (Bergh.), doi: 10.1094/APSnetFeature-2000-0300.

Malinowski, T., M. Cambra, N. Capote, M.T. Gorris, R. Scorza, and M. Ravelonandro. 2006. Field trials of plum clones transformed with the Plum pox virus coat protein $(\mathrm{PPV}-\mathrm{CP})$ gene. Plant Dis. 90:1012-1018.

Polak, J., J. Jarosova, J. Kumar, J. Sochor, R. Kizek, B. Krška, K. Gogolkova, M. Ravelonandro, and R. Scorza. 2013. The evaluation of virus symptoms and fruit quality of GMO, PPV resistant $P$. domestica 'HoneySweet' grown in the open field under a high and permanent infection pressure of PPV ACLSV, and PDV. Acta Hort. 974:65-70.

Polak, J., J. Kumar, B. Krska, and M. Ravelonandro. 2012. Biotech/GM crops in horticulture: Plum cv. HoneySweet resistant to Plum pox virus. Plant Protect. Sci. 48:S43-S48.

Polak, J., J. Pivalova, J.K. Kundu, M. Jokes, R. Scorza, and M. Ravelonandro. 2008. Behaviour of transgenic Plum pox virus-resistant Prunus domestica L. clone $\mathrm{C} 5$ grown in the open field under high and permanent infection pressure of the PPV-Rec strain. J. Plant Pathol. 90:S1.33-S1.36.

Ravelonandro, M., R. Scorza, J.C. Bachelier, G. Labonne, L. Levy, V. Damsteegt, A.M. Callahan, and J. Dunez. 1997. Resistance of transgenic Prunus domestica to Plum pox virus infection. Plant Dis. 81:1231-1235.

Ravelonandro, M., P. Briard, M. Monsion, and R. Scorza. 2002. Stable transfer of the Plum pox virus (PPV) capsid transgene to seedlings of two French cultivars 'Prunier d'Ente 303' and 'Quetsche 2906', and preliminary results of PPV challenge assays. Acta Hort. 577:91-96.

Ravelonandro, M., R. Scorza, J. Polak, A. Callahan, B. Krška, J. Kundu, and P. Briard. 2013. "HoneySweet" plum: A valuable genetically engineered fruit-tree cultivar. Food Nutr. Sci. 4:45-49.

Ravelonandro, M., R. Scorza, J.M. Hily, and P. Briard. 2014. The efficiency of RNA interference for conferring stable resistance to Plum pox virus. Plant Cell Tiss. Organ Cult. 118:347-356.

Scorza, R. and H.W. Fogle. 'Bluebyrd' plum. 1999. HortScience. 34:1129-1130.

Scorza, R., M. Ravelonandro, A.M. Callahan, J. Cordts, M. Fuchs, J. Dunez, and D. Gonsalves. 1994. Transgenic plums (Prunus domestica L.) express the Plum pox virus coat protein gene. Plant Cell Rpt. 14:18-22.

Scorza, R., A. Callahan, C. Dardick, M. Ravelonandro, J. Polak, T. Malinowski, I. Zagrai, M. Cambra, and I. Kamenova. 2013a. Genetic engineering of Plum pox virus resistance: 'HoneySweet' plum: From concept to product. Plant Cell Tiss. Organ Cult. 115:1-12.

Scorza, R., A. Kriss, A. Callahan, K. Webb, M. Demuth, and T. Gottwald. 2013b. Spatial and temporal assessment of pollen- and seedmediated gene flow from genetically engineered plum. PLoS One 8:e75291.

Scorza, R., A.M. Callahan, L. Levy, V. Damsteegt, and M. Ravelonandro. 1998. Transferring Potyvirus coat protein genes through hybridization of transgenic plants to produce Plum pox virus resistant plums (Prumus domestica L.). Acta Hort. 472:421-427.

Scorza, R. and M. Demuth. 2015. Black knot [Apiosporina morbosa (Schw.)] resistance in imported and domestic Prunus domestica L. germplasm and cultivars. J. Amer. Pomol. Soc. 69:45-50.

Sochor, J., B. Krska, J. Polak, and T. Jurikova. 2015. The influence of virus infection on antioxidant levels in the GM plum variety "HoneySweet" (Prunus domestica L.). Potravinarstvo Sci. J. Food Ind. 9:1-5.

Zagrai, I., N. Capote, M. Ravelonandro, M. Cambra, L. Zagrai, and R. Scorza. 2008. Plum pox virus silencing of $\mathrm{C} 5$ transgenic plum is stable under challenge inoculation with heterologous viruses. J. Plant Pathol. 90:S63-S71.

Zagrai, I., M. Ravelonandro, L. Zagrai, R. Scorza, and N. Minoiu. 2011. Overview of the investigations of transgenic plums in Romania. Acta Hort. 899:153-158. 